\title{
Freedom of the Press Regulations in Indonesia and Sweden: Limited but Free
}

\author{
http://dx.doi.org/10.25008/jkiski.v6i2.609
}

\author{
Haresti Asysy Amrihani ${ }^{1}$, Rajab Ritonga ${ }^{2}$ \\ ${ }^{1}$ Department of Communication, Faculty of Social and Political Science, Universitas Airlangga \\ Jl. Dharmawangsan Dalam, Surabaya 60286 - Indonesia \\ ${ }^{2}$ Communication Study in Postgraduate Programme, Institut Komunikasi dan Bisnis LSPR \\ Sudirman Park, Jl. KH. Mas Mansyur Kav. No. 35 Jakarta 10220 - Indonesia \\ *Corresponding author: haresti.asysy.amrihani-2021@fisip.unair.ac.id
}

Submitted: November 30, 2021, Revised: December 10, 2021, Accepted: December 26, 2021

Accredited by Kemristekdikti No. 28/E/KPT/2019

\begin{abstract}
Freedom of the press regulations are adhered to by various countries, including Indonesia and Sweden. Every nation wants their country to be free, and uphold freedom of expression and human rights. Sweden is the first country to regulate freedom of expression by enacting Freedom of the Press Act in 1766, while Indonesia has so far implemented Law No. 40 of 1999 on the Press. This article highlights how freedom of the press is implemented in Indonesia so that its index of democracy and freedom of the press is equal to that of Sweden. This research applies a literature study method and uses secondary data from various books, journals and legislations. The researcher concludes that some groups encourage the revision of Law No. 40 of 1999 with certain conditions, while others are opposed to it. The other groups stated that the law is lex specialis derogate legi geneari and is used in case of press dispute so that journalists can no longer be imprisoned due to their profession.

Key words: media regulations; freedom of the press; freedom of expression; freedom of the press index index, fourth pillar of democracy.
\end{abstract}

\section{Introduction}

For the first time ever, Indonesia adopted the press law during the turn of President Soekarno's government by issuing Law No. 11 of 1966 on Principal Provisions of the Press. During the New Order era, the law was twice revised into Law No. 21 of 1982 on Amendment to Law No. 11 of 1966 as already amended by Law No. 4 of 1977. The law, both in the Old Order and New Order eras, mentioned freedom of the press through a clause "the national press is not subject to closure" but the reality was different. The government shackled and controlled the press by issuing various regulations which allowed for the closure of publishing firms by revoking their publishing permit or press publication permit.

The downfall of the New Order regime in 1998 has given birth to the new stage of the national press with the issuance of Law No. 40 of 1999 on the Press which is still valid until now. Since then, the government has no longer shut down publishing firms. The reform era gives the press an honorary position and make the press the fourth pillar of democracy. Consequently, Indonesia is dubbed the world's third largest democratic country after the United States and India. Without independent press, there will not be democracy, freedom of expression and human rights (Manan, 2012).

Article 2 of Law No 40 of 1999 on the Press stipulates that freedom of the press is one of the manifestations of the people's sovereignty based on the principles of democracy, justice and legal supremacy. Through the clause, the press has clear position to execute the people's sovereignty because the 
country belongs to the people and thus, the press deserves as wide freedom as possible to realize the people's mandate (Lesmana, 2005). Although Indonesia adopts free press, violence against journalists still occurs. Data from the Independent Journalists Alliance (AJI) show throughout 2019 there were 53 cases of violence against journalists and presence of journalist unfriendly regulation (Press Council, 2021).

This press law is often dubbed a hastilyproduced law since it was submitted to the parliament only one year after the reform movement was launched in 1998. At that time, only a few legal experts were involved in drafting the press bill and empirical experiences in handling press offenses were still limited (Rachman, 2011) as the consequence of shackled national press during 32 years of the New Order government. The press bill was for the first time deliberated on August 20, 1999 and endorsed on September 13, 1999. It was not until September 23, 1999 the bill with reform content was passed into law. Until now the law does not require implementation regulation such as government regulation.

The Press Law No. 40 of 1999 carries several progressive steps such as (1) media companies no longer need Press Publishing Permit (SIUPP); (2) media companies are exempt from closure; (3) the Press Council is fully free from the government's interference (independent); (4) there is no longer a single journalists association as what happened during the New Order era. However, the Press Law No 40 of 1999 has created new problems which remain unsolved until now. One of the points which often cause problems is that the press law does not align with the Penal Code (KUHP) in protecting journalists and media companies. Law enforcers prefer the Penal Code to the Law No. 40 of 1999 to settle press disputes. As a result, journalists in Indonesia are under a threat of imprisonment because their journalistic works are against the law.

For example, Editor-in-Chief of Rakyat Merdeka Daily Karim Paputungan was declared guilty of violating Article 310 paragraph 2 of the Penal Code and sentenced to five months in jail with a probation period of ten months for insulting House Speaker and Golkar Party Chairman Akbar Tanjung through Rakyat Merdeka Daily's caricature on January 8, 2002. In the following year, Executive Editor of Rakyat Merdeka Daily Supratman was sentenced to six months in jail with a probation period of 12 months. He was declared guilty of violating Article 137 paragraph 1 of the Penal
Code for attacking the dignity of President Megawati Soekarnoputri though his news stories titled "Mega's Mouth Smells Diesel Oil", "Mega is More Cruel than Sumanto", "Mega is in the Same Class as Regent". There are still many other journalists sentenced to jail using the Penal Code.

The latest case involved journalist Muhammad Asrul who wrote a story about an alleged corruption case in Palopo, South Sulawesi. The public prosecutor demanded that Asrul be sentenced to one year in jail for allegedly violating Article 45 paagraph 1 adj. Article 27 paragraph 3 of the Electronic Information and Transaction Law on October 13,2021 . The judge later sentenced him to three months in jail on November 23, 2021. The Legal Aid Foundation for the Press (LBH Pers) is of the view that Arsul case is a journalistic dispute so that it must be settled through mediation at the Press Council (Taher, 2021).

Journalists are often accused of besmirching reputation through their stories. Indeed, the Press Law No. 40 of 1999 does not discuss defamation and slander. It is different from the Penal Code which clearly regulates the matter in details. In Law No. 40 of 1999, criminal provisions are provided for in Article 18 paragraph (1), where anybody who obstructs the press from carrying out a journalistic task, seeking, obtaining and disseminating ideas and information (Article 4 paragraph 3 ) is liable to a maximum sentence of two years' imprisonment and a maximum fine of Rp500,000,000. Similar criminal sanctions also apply to anybody who is involved in press censorship, media closure, or banning publication (Article 4 paragraph 2).

Criminal sanctions may also be imposed on media company that publishes an event and opinion by paying no respect to religious norms and social ethics and violating the presumption of innocence principle (Article 5 paragraph 1), does not serve the right of reply (Article 5 paragraph 2), and publishes advertisements by underestimating religious dignity, disturbing religious harmony and social ethics, or carrying liquor, drug, psychotropic and other addictive substance advertisements (Article 13). Media company that commits all the violations may be liable to a maniximum fine of Rp500,000,000 and a fine of Rp100,000,000 if it does not have Indonesian legal entity and mention name, address and person in charge openly (Article 12).

Criminal sanctions which are most frequently faced by journalists are related to 
articles about insult, hate speech, and defamation as provided for in the Penal Code. The Press Law No. 40 of 1999 should clearly define the meaning of insult so that people will not easily accuse the press of insulting them or besmirching their reputation. Referring to criminal provisions in Article 18 of Law No, 40 of 1999, the study formulation is how Law No. 40 of 1999 as lex spesialis is always used to try press disputes.

\section{Theoritical Framework}

\section{Post-Reform Press Regulation in Indonesia}

The Indonesian press experiences an extraordinary change in the wake of May 1998 reform, particularly when it comes to freedom of expression. This is also marked by the emergence of new print, television and cyber media companies which continue to grow. Data from the Press Council in 2021 show that there are 1,684 verified media companies, including print media, television, radio and online media (Press Council, 2021) out of the predicted 120,000 mass media or more.

With the downfall of the New Order regime, one of the important reform agenda is the enactment of Press Law No. 40 of 1999. The government under the leadership of President BJ Habibie assured freedom of the press. There is no longer obligation for anybody to secure a press publishing permit (SIUPP) to set up a media company (Nugroho, Y., Siregar, M, F \& Laksmi, 2013). As a result, many media companies flourish. Journalists compete with one another to write stories as freely as possible. The press is so free that the meaning of press freedom is diverted to "outrageous free press" by those who are concerned about free and uncontrollable press.

Actually, the interpretation of freedom of the press in this democratic state has various dillemas. In practice, although the Indonesian press is free, the freedom is considered to have not fully served public interests but interests of certain groups. In this context, the issue of interpretating the concept of press freedom and public interest has increasingly surfaced. Actor and medkia player often have different understanding, interpretation and conceptualization of press freedom and public interest (Nyarwi, 2020).

On the other hand, this post-reform condition should show that there is nothing for media players including journalists to be afraid of while performing their journalistic duties. As a matter of fact, journalists have not fully felt secure to perform their journalistic duties.
According to Martini (2014), free and active press is one of the most essential components of the community that claim to be a democractic state. The balance between freedom of the press and their social responsibility is important.

Democratic press system has three characteristics (Gunarjo et al, 2013). First, journalist's freedom. Freedom of the press must be directed towards benefiting the public (McQuail, 2002). Freedom of the press is a means of public empowerement because it calls for the participation of the public as a social force, and the state and its apparatuses as a political force to build and encourage press democratization (Severin \& Tankard, 2005). Second, free access. Free access is aimed at ensuring the availability of information in the heterogenous community so that they can choose information according to their needs (Subiakto, 2001). Third, transparent public space. The community should use public space to discuss, convey opinion and express stand and argument to the state and government freely and transparently (Habermas, 1989).

Viewed from the process of enacting the Press Law No. 40 of 1999, it is obvious that those involved in drafting the law gave as wide freedom as possible to journalists to express their works. This view leads to stand that situation must be created as far as possible to enable journalists to perform their duties. On the contrary, this can divert the direction from the aim of increasing freedom of the press. The absence of rules to standardize journalistic profession in the Press Law has allowed all people to be able to become journalists without significant qualifications. As a result, the professional quality of journalists becomes a problem (Sukardi, 2012).

The presence of many unprofessional and incompetent journalists may have a bad impact on freedom of the press. As stated by senior journalist Ilham Bintang in Sukardi (2012), press regulation does not merely give freedom to anybody to establish a media company, including the absence of restrictions to set up a journalists association. Consequently, small scale media companies are flourishing and the population of unprofessional journalists paid less than provincial minimum wages is increasing.

Unprofessional journalists who have no knowledge of journalistic code of ethics will fearfully produce bad journalistic works. Not only do they disturb informants and the public but also threaten the freedom and credibility of the press. For this part, the Press Council has 
issued Competency Standard for Journalists and Standard for Press Companies.

The presence of the Press Law No. 40 of 1999 is like a double-edged sword. On one hand, the press law brings about development and freedom of the press in Indonesia. But on the other hand, it still has several shortcomings because law enforcement officers often ignore it to try press disputes. Therefore, some parties opined that the time has come to revise the press law, while other parties believed that it does not need to be revised.

Sukardi (2012) stated that there are two groups that opine whether or not the press law needs to be revised, namely (1), the group opposing the revision and (2), the group favoring the revision.

\section{The Group Opposing Revision}

Actually, this group is aware that Press Law No. 40 of 1999 has shortcomings in its application. This group is also aware of provisions in the law that can harm freedom of the press. This group has reasons why they are against the revision, among others: (1) Although the press law has shortcomings, in reality it proves effective to support freedom of the press. Despite the shortcomings and weaknesses, the press law is able to build new paradigm of the Indonesian press and by thus far, it still can overcome various shortcomings; (2) In view of the characteristics of authority that tends to maintain power, the revision of the press law may produce press law which will be far worse than the existing press law. The situation of post-reform political power map is not conducive to revise the press law. In the process of revising the press law, the authority is believed to enter and protect their power interests so that it will collide with freedom of the press. It is almost certain the existing press protection will be sacrificed. Thus, the result will not be improving freedom of the press but weakening freedom of the press; (3) It would be better to protect the formulation of various other bills from reducing freedom of the press rather than to revise the press law. If the other laws do not support freedom of the press, the revision of the press law will be meaningless. In contrast, if many articles in the other laws protetct freedom of the press, provisions in the Press Law No. 40 of 1999 have been sufficient.

\section{The Group Favoring Revision}

This group opines that the Press Law No. 40 of 1999 should be amended soon. Judicially, this group opines the law is much flawed Unless it is ameded soon, the interests of the general public, the nation and the state will be harmed very much. The reasons of this group are, among others: (1) The presence of the press after the enactment of Press Law No. 40 of 1999 has been much used to damage legal supremacy undemocratically through publications carrying character assassination. Consequently, instead of giving political and legal education, the press has created anarchic and temperamental community; (2) Press Law No. 40 of 1999 is much used to serve the interests of certain individuals or groups by discrediting other parties that are against the certain individuals or groups to protect their interests; (3) Press Law No 40 of 1999 has indirectly "protected" and/or given a chance to journalists involved in swindle, extortion and intimidation on the pretext of upholding democracy because it restricts legal proceedings against them; (4) Law enforcers get confused due to the absence of clarity to use law to settle press disputes.

\section{Group Favoring Revision with Certain Conditions}

This group looks at two sides all at once. On the first side, this group sees the enactment of Press Law No. 40 of 1999 has successfully freed the press from the shackles of authority. On the second side, this group realistically accepts the reality that this law still has several shortcomings. Therefore, if the press law is revised, then only the problematic parts should be revised without touching freedom of the press.

This group gives notes including: (1) Make sure that only the technical part of law formulation will be revised without amending the paradigm of freedom of the press. To that end, before deliberations are started, there must have been a draft revision of the law approved by all sides; (2) Make sure that all sociopolitical powers, compositions at the House of Representatives (DPR) and all relevant parties agree and support the revised items which are technical part and do not disturb freedom of the press; (3) Make sure that the revision is conducted at the request of the press and in the interest of the press. If the conditions are not met, this group opine Press Law No. 40 of 1999 which has shortcomings is still far better and more effective to maintain freedom of the press than proposing the revision of the law which entails a greater risk. 


\section{Press Regulation in Sweden}

Since freedom of information act was for the first time endorsed in the Swedkish and Finnish territory in 1766, more than 90 countries have endorsed similar acts so far. However, the implementation of the acts in various countries still face many problems (Winarto, 2016). According to data from Reporters Without Borders, in 2021 Sweden was ranked third in terms of freedom of the press index worldwide. The rank increases from the previous year when the country was ranked fourth. In 2021, no murder of journalist and media worker was reported in Sweden (Reporters Without Borders, 2021).

The Swedish act is considered to be the first act in the world supporting freedom of the press and freedom of information (freedom of the press act of 1766). Up till now, the European country still has the highest rank in terms of media independence (Puspitaningrum, 2019). The Swedish press act was endorsed by the Swedish Parliament (Riksdag) as a rule related to freedom of expression and writing. The freedom of the press act abolishes censorship of all print publications, including those imported but excluding those related to academic and theological materials. In addition, this act also ensures public access to documents made by government institutions. Howeve, journalists will face heavy penalty if they are opposed to the state or king (Delphipages, 2020).

In Nordic countries including Sweden media organizations and communication continue to grow. The press in the region is supported by the public but continues to uphold independence. This makes Nordic a region with the highest readership in the world. The broadcast institutions funded and owned by the public have contributed to developing national identity, including securing all of the population's accesses to high speed internet services (Syversten, et al, 2017).

The state's wide intervention in the region and the public's strong adherence have helped create freedom of speech. The result is adaptive public media sector with high legitimacy in local and global regions (Yonas, 2021). This country respects media independence and has media ombudsman to handle complaints and problems related to the journalistic code of ethics. But this does not mean that journalists do not become the target of threat, online hate and lawsuit from other parties (Reporters Without Borders, 2021).
Sweden is also concentrated by media conglomerates. Herutomo (2003) stated, the rising media monopoly and ownership concentration has reduced the number of free voices heard in an open debate. This happens because many newspapers and broadcast stations are part of media conglomeration. In several democratic countries such as Norway and Sweden, the government maintains diverse political views by providing assistance to newspapers. This condition is actually a form of practice which is not without potential danger to freedom of the press.

Meanwhile, since 2020, the management of the media sector and its economic model has changed due to COVID-19 pandemic. The print media in Sweden shifts to online media and the economic model changes from advertisement to subscription. The COVID-19 pandemic also has a negative impact on the principle of openness in Sweden because the authority denies the media's access to state documents related to the pandemic. A decline in advertisement revenues has caused financial difficulties to several media companies and state subsidies increase to more than double. But on the other hand, the pandemic has raised the Swedish community's interest to read news stories because they are aware of the significance of factual and relevant reporting (Reporters Without Borders, 2021).

Sweden's Director General of Press, Radio, and Television (Myndigheten for Press, Radio och TV), Charlotte Nilson explained the status of broadcast institution he led and his authority to regulate media is different from that of Indonesia. Although both are broadcast regulator, Myndigheten for Press, Radio och TV is a state institution overseen by the Swedish Ministry of Culture. The vision of the broadcast institution is to maintain freedom of the press and diversity. This institution is also aimed at fighting against the impact of danger caused by media. In addition, the significant difference between the authority of the Indonesian Broadcast Commission (KPI) and Myndigheten for Press, Radio och $T V$ is the scope of supervision also covering the press, both newspaper and online portal (Ira, 2019).

Meanwhile, the factors that cause freedom of the press in Sweden are as follows:

(1) Foundations in Sweden help finance media outlets. As such, the media is expected to focus on professional tasks which uphold the principle of journalism and freedom of expression. The foundations are philanthropic and commercial foundations. These foundations also support journalism, 
particularly investigative journalism which eventually produce the phenomenon of "nonprofit journalism" (Kinkel, 2020);

(2) Government subsidies have stabilized the market and encouraged innovations. Digitalization changes media business patterns in Sweden. Any sort of information from all over the world can be accessed digitally and on average, it is free. This disruption has put pressure on the economy of media, particularly local and regional media. Hence, subsidies are needed by media to survive (Yonas, 2021). The subsidies are classified into subsidies directly given to media and subsidies in the form of tax relief for newspapers;

(3) Labour unions participate in protecting journalists and conserving professional journalism. That is what will happen if democracy functions properly. Labour unions can fully develop their potentials and serve as a strong and independent actor in struggling for workers' rights including economic welfare (Schroeder in Yonas 2021);

(4) Linkage between public media institutions and audience has successfully built trust. Globally, public broadcast institutions have faced new challenges to carry out their roles. Some of them are that they must adapt to digital era, maintain principles of journalism amidst economic and political power, secure funding and maintain the high editorial standard amidst the competitive market. Therefore, a public state institution, public broadcast services play an important role in creating democracy. When citizens are convinced that their public broadcast institutions are politically independent, then the community tends to be more satisfied and democratic (Rosa in Yonas, 2020);

(5) The protection of journalistic ethics through a self-reliant regulation. As written by European Centre for Press and Media Freedom (2020), the Swedish Press Council described how they can function independently as an important factor to encourage responsible journalism. Sweden has national media ombudsman that plays a role in ensuring that the journalistic ethics are upheld.

(6) Strong constitutional protection gives security to freedom of media. All EU member states are bound to 10 articles of European Convention of Human Rights which ensures freedom of the press and the rights of journalists to access public documents, collect data, and conduct investigation. Sweden has effectively succeeded in creating environment which allows for freedom of the press, transparency, the strong rights of journalists and respect for constitutional principles related to freedom of the press. Sweden has more than 250 years of tradition to protect freedom of the press (Voorhoof, 2020).

The freedom of the press act in Sweden has been adopted by the Swedish Parliament since 1766. At that time, Finland was still integrated with the Swedish Kingdom. The act endorsed on December 2, 1766 is the first freedom of the press act in the world. The act contains provisions on freedom of writing and printing, as well as censorship ban. What is the breakthrough of the act is content on the right to obtain documents from the government authority Swedish Parliament, 2018).

\section{Material and Methodology}

This research is a literature review or literature research, that is the researcher reviews and studies critically a knowledge, idea or finding in a literature by conducting academic orientation, formulating and constructing theoretical and methodological contributions for a certain topic (Marzuki, 2005).

According to Cresweel (2014), literature review is a written summary of article from journal, book, and other documents which describes theory and information, both in the past and in the present, organize literature into a topic and document needed. The focus of literature review is to find various ideas, argumentations, theories, principles or laws used to review and analyze them as part of efforts to answer the formulated research questions. Analytical method in this research using literature review is descriptive analytical, that is interpretation of ideas or information, data conducted regularly and explained clearly in order to understand it.

Data collection technique is obtained through articles from national and international journals, books, documents and publications related to the topic of this research. The researcher gathered data or sources related to the topic of this research. The data were later analyzed using a descriptive analytical method after passing through the stages of data reduction and data collection. Descriptive analytical method is conducted by describing and analyzing facts so that the researcher not only describes but also explains them.

\section{Result and Discussion}

Comparison of Freedom of the Press in Indonesia and Sweden 
Freedom of the press is a condition desired by almost all journalists in the world. The United Nations has declared May 3 as World Press Freedom Day. The event is commemorated to increase awareness of the significance of freedom of the press and to remind governments of their tasks to respect and uphold rights to freedom of expression.

Indonesia is one of the countries that adopt press law. The Indonesian press law was enacted in 1999, one year after the downfall of New Order regime and the launch of Reform Order. Press Law No. 40 of 1999 is the fruit of the reform movement's struggle to create the fourth pillar of democracy.

According to data from Reporters Without Borders, Indonesia was ranked 113th out of 180 countries surveyed for freedom of the press index in 2021. Quoting the result of a survey conducted by Superintending Company of Indonesia (Sucofindo), Indonesia's freedom of the press index increased 0.75 in 2021 (Savitri, 2021). This means that Indonesia is under the fairly free category in terms of freedom of the press.

Press Law No. 40 of 1999 in points a and $\mathrm{b}$ of consideration states that freedom of the press is one of the manifestations of the people's sovereignty and is an essential element to create democratic life of communityhood, nationhood and statehood so that freedom of expression as referred to in Article 28 of the 1945 Constitution must be guaranteed; that in the life of communityhood, nationhood and statehood, freedom of thoughts and opinions according to conscience and the rights to information is very essential human rights needed to uphold justice and truth, promote public welfare and intellectualize the nation.

The right to information is actually the right of every citizen and is not merely the right of journalists while performing their duties. Journalists actually work on behalf of the public. As stated by Sukardi (2012), although the law is press law this law basically applies not only to the press but also the entire nation. Indeed, the press law contains several provisions on journalists and media companies such as the use of right to reply and the public right to file analysis of the press' misreporting and the right to file suggestions to the Press Council.

In reality, freedom of the press guaranteed by the constitution and law has not been fully implemented, except on the early days of reform euphoria from 1998 to 2014. Since then, threat and violent act against the press began to occur. When a legal case related to journalistic product happens, law enforcers use the Penal Code or Law No. 19 of 2016 on Amendment to Law No. 11 of 2008 on Electronic Information and Transaction (ITE) instead of the press law. The case should first be settled by the Press Council. In addition, some journalists have not performed their duties in accordance with the journalistic code of ethics.

Several cases befell journalists in 2019. According to SAFEnet's record, eight journalists were tried using Law on Electronic Information and Transaction (UU ITE). Some of them were Dandy Laksono (Watchdog journalist), Muhammad Sadli Saleh (liputanpersada.com journalist), Muhammad Asrul (beritanews.com journalist), M Reza (realita.com journalist), and Gencar Djarot (owner of koranindigo.online).

The cases arouse a question "whether the time has come to revise the Press Law No. 40 of 1999?" The question evokes several responses, among others: (1) group opposing revision; (2) group encouraging revision and (3) group favoring revision with conditions.

The group opposing revision of Press Law No. 40 of 1999 stated they are aware that the press law has shortcomings. However, the law is still effective to support freedom of the press. If revised, this group is worried that certain parties will enter their interests which run counter to freedom of the press.

The group favoring immediate revision believes the press law is judicially flawed. This law provides opportunities to journalists to commit swindles. In addition, many provisions in the law contradict one another so that law enforcers get confused in the absence of clarity about which law must be applied.

The group favoring revision with conditions stated efforts must first be made to ensure which part of the law will be revised. They opine that only technical part of law formulation should be revised, rather than to change the paradigm of press freedom. In addition, the revision must come from the press in the interests of journalists and not frrom other party.

Actually, if seen farther, the obstacle rests with law enforcement. Any case related to the press should be settled through the press law, rather than the Penal Code or ITE Law. There must be a firm distinction between press offense and non-press offense. One thing that should draw attention is the presence of materiil sphere from the press law whether it is General Criminal Law or Special Criminal Law, 
because the cases are treated differently. Later the criminal accountability must be stressed whether it is for individual or corporation (institution).

Sweden which is ranked third in terms of freedom of the press index may serve as a reference to uphold freedom of the press. In addition to being the first country in the world to adopt Freedom of the Press Act in 1776, Sweden is one of the countries which highly respect media independence and have media ombudsman to handle problems and complaints about the journalistic code of ethics.

The far difference between the freedom of the press indexes of Indonesia and Sweden suggests that there must be distinctive things between the two countries. Indonesia has greater population than Sweden. According to data from the Foreign Ministry, Sweden had a population of 9,816,666 and its territory covers an area of 450,295 square kilometers (Kemlu, 2021). It is different from Indonesia which had a population of $272,229,372$ and its territory covers an area of 5,919,440 square kilometers (Kemedagri, 2021). Of course, this makes Indonesia and Sweden have special uniqueness in terms of press regulation.

In addition, Sweden is ranked first in the world in terms of the quality of the public's education. Of course, this influences media consumption in the community and the programs of media authority to counter the negative impact of media. The high level of media literacy and press awareness surely contributes to the control of news contents so that the quality of the press is also getting better.

\section{Conclusion}

Of course, the press regulations applied in Indonesia and Sweden are different since the number of their population and the area of their territory are also different. However, the two countries continue to maintain freedom of the press. Sweden's freedom of the press index sets an example for Indonesia to uphold freedom of opinion.

In the meantime, the press regulation in Indonesia is debated whether to change or maintain it. However, if it is revised without considering several studies, the revision may endanger freedom of the press. Don't let the revision of the press law turn into a "wild ball" that allows certain quarters to control again the press at the expense of freedom of the press.

Although groups oppose, favour and favour the revision with conditions, the Press Law No.40 of 1999 as lex specialis derogate legi geneari should be used in the case of press dispute. The legal mechanism of lawsuit should be explained so that cases that should be settled through the press law will no longer be settled through the Penal Code or ITE Law. As such, no journalists will be imprisoned because of their profession.

\section{References}

Aditya, N. (2020, November 18). Catatan SAFEnet: 8 kasus jurnalis terjerat UU ITE sepanjang 2019. Kompas. com. https://nasional.kompas.com/read/2020/1 1/14/05050021/catatan-safenet--8-kasusjurnalis-terjerat-uu-ite-sepanjang2019? page $=$ all.

Creswell, J. (1998). Qualitatif inquiry and research design: Sage Publications.

Delphipages. (2020, September 2). Undangundang Kebebasan Pers 1766 Legislasi Swedia. Delphipages.live. https://delphipages.live/id/politikhukum-pemerintahan/hukum-kejahatanhukuman/freedom-of-the-press-act-of1766.

European Centre for Press and Media Freedom. (2020). Media Freedom Made in Scandinavia.

Dewan Pers. (2021, November 13). Data Perusahaan Pers. Dewanpers.or.id. https://dewanpers.or.id/data/perusahaanp ers.

Dewan Pers. (2006, November 14). Undangundang No 40 tahun 1999 tentang Pers. Dewanpers.or.id. https://dewanpers.or.id/assets/documents luu/UU Nomor 40 Tahun 1999.pdf.

Gunarjo, et al. (2013). Dilema pers birokratik di era demokratisasi studi kasus tabloid komunika kementerian komunikasi dan informatika. Jurnal Kawistara, 3(1), 7993.

Habermas, J. (1989). Ruang publik, sebuah kajian tentang kategori masyarakat borjuis. Kreasi Wacana.

Herutomo. (2003). Perbandingan sistem pers. Sumatera Utara: USU Digital Library.

Ira. (2019, November 15). Kunjungi Swedia, KPI pelajari regulasi media di negara kualitas pendidikan terbaik. Kpi.go.id. http://www.kpi.go.id/index.php/id/umum /38-dalam-negeri/35204-kunjungiswedia-kpi-pelajari-regulasi-media-dinegara-dengan-kualitas-pendidikanterbaik?detail $3=5444$. 
Kemendagri. (2021, November 18). Data kependudukan semester I tahun 2021. Kemendagri.go.id.

https://dukcapil.kemendagri.go.id/berita/ baca/809/distribusi-penduduk-indonesiaper-juni-2021-jabar-terbanyak-kaltarapaling-sedikit.

Kemlu. (2021, November 18). Profil negara dan kerjasama Kerajaan Swedia. Kemlu.go.id.

https://kemlu.go.id/stockholm/id/pages/h ubungan_bilateral/667/etc-menu.

Kinkel, L. (2020, November 17). Foundations help media outlets to focus on professional journalism and media freedom. Ecpmf.eu.

https://www.ecpmf.eu/wpcontent/uploads/2020/05/ECPMF-FFMScandinavia_2020.pdf.

Lesmana, T. (2005). Kebebasan pers dilihat dari perspektif konflik, antara kebeasan dan tertib sosial. Jurnal Ilmu Komunikasi, 2(1), 1-14.

Manan, B. (2012). Politik Publik Pers. Dewan Pers.

Martini, R. (2014). Analisis peran dan fungsi pers sebelum dan sesudah reformasi politik di Indonesia. Jurnal Ilmu Sosial, 3(2), 1-9.

Marzuki, P, M. (2005). Penelitian Hukum. Prenada Media.

McQuail, D. (2000). Mass Communication Theories. Sage Publications.

Nyarwi. (2020). Kebebasan pers dan kepentingan publik. Jurnal Ilmu Komunikasi, 9(1), 1-15.

Nugroho, Y., Siregar, M.F., \& Laksmi. (2013). Memetakan kebijakan media di Indonesia (edisi Bahasa Indonesia). Jakarta: CIPG dan HIVOS.

Puspitaningrum, C. (2019, September 6). Didominasi Eropa, ini 5 negara dengan kebebasan pers terbaik. Akurat.co. https://akurat.co/didominasi-eropa-ini-5negara-dengan-kebebasan-pers-terbaik.

Ranchman, A. (2011, November 17). Pakar hukum: UU Pers miliki lima kelemahan. Republika.co.id.

https://www.republika.co.id/berita/ll3xx d/pakar-hukum-uu-pers-miliki-limakelamahan.

Reporters Without Borders. (2021, November 17). Sweden. https://rsf.org/en/sweden.

Reporters Without Boreders. (2021, November 18). 2021 World Press Freedom Index. Rsf.or. https://rsf.org/en/ranking?\#.
Savitri, P. (2021, November 18). Survei: Indeks kemerdekaan pers Indonesia 2021 meningkat. Antaranews.com. https://www.antaranews.com/berita/2364 438/survei-indeks-kemerdekaan-persindonesia-2021-meningkat.

Severin,W. \& Tankard, J. (2005). Communication Theories. Kencana.

Subiakto, H. (2001). Menggagas system media yang demokratis untuk Indonesia baru. Jurnal Ikatan Sarjana Komunikasi Indonesia, 6(11), 9-29.

Sukardi, W, A. (2012). Kajian tuntas 350 tanya jawab UU Pers dan Kode Etik Jurnalistik. Dewan Pers.

Swedish Parliament. (2018). Press freedom 250 years freedom of the press and public access to official documents in Sweden and Finland. Sveriges Riksdag.

Syversten, T, et al. (2017). The media welfare state. San Francisco: University of Michigan Press.

Taher, A.P. (2021, October 19). Janggalnya kasus jurnalis Asrul: Abaikan UU Pers dan dijerat UU ITE. Tirto.id. https://tirto.id/janggalnya-kasus-jurnalisasrul-abaikan-uu-pers-dijerat-uu-itegkwL.

Voorhoof, D. (2020). Sustainable co-and selfregulatory frameworks promoting and safe-guarding ethical journalism. European Centre for Press \& Media Freedom.

Winarto. (2016). Indonesia menyongsong Jakarta world forum form media development 2016. Jurnal Dewan Pers, 12, 3-97.

Yonas, A, R. (2021, November 17). Upaya negara-negara Nordik dalam menjamin kebebasan pers di tengah disrupsi digital. Psdr.lipi.go.id. http://psdr.lipi.go.id/news-andevents/opinions/upaya-negara-negaranordik-dalam-menjamin-kebebasanpers-di-tengah-disrupsi-digital.html 